\title{
Daniel Joslyn-Siemiatkoski The More Torah, the More Life: A Christian Commentary on Mishnah Avot
}

(Leuven: Peeters, 2018), 394 pp.

\author{
NOAH BENJAMIN BICKART \\ nbickart@jcu.edu \\ John Carroll University, University Heights, OH 44118
}

As a professor of Jewish studies at a Catholic university, my major challenge is to enable my students to see Judaism not only as the ancient context from which Jesus and Christianity emerged but as a living tradition which has developed alongside Christianity through the present. Even when students reject all the negative connotations of supersessionism, in their theological chronologies they view Christianity as a later development and thus as a replacement of an earlier Judaism.

To my students I have often argued (admittedly simplistically) that the Mishnah (or the Tannaitic oeuvre) ought to be seen as the "New Testament" of Rabbinic Judaism. The Rabbis claim both to be in full continuity with biblical and pre-Rabbinic Judaism while in many other regards they are forging a new religious path. It has become fashionable in recent years for Jews to write commentaries on the New Testament not simply as dispassionate scholars who happen to be Jewish but as Jewish scholars reading Christian writings as Jewish literature for, among others, contemporary Jewish readers. Marc Zvi Brettler and Amy-Jill Levine's The Jewish Annotated New Testament (first published in 2011) has pride of place in this regard. As such, Daniel Joslyn-Siemiatkoski's new explicitly Christian commentary on tractate Avot from the Mishnah, The More Torah, the More Life, represents the same kind of approach from the other direction.

After an introduction to the tractate and to his approach, much of the book presents Joslyn-Siemiatkoski's adaptation of a classical Rabbinic genre, the verseby-verse commentary. Each section opens with an English translation of the H. Albeck text, followed by "Jewish Interpretations" and then "Christian Resonances." This structure allows for a clear presentation of what the author terms a "Comparative Theology approach," which "does not appropriate the text for its own purposes but dwells within its meanings" (p. 4). As such the goal of the commentary is neither the search for Rabbinic influences on Christianity nor for 
parallels between Rabbinic and New Testament texts. Rather, the goal is for Christian readers to learn something about this text at the center of the Rabbinic cannon, and, perhaps more importantly, to enrich their own religious life by encountering and taking seriously the religious claims found therein.

Joslyn-Siemiatkoski's treatment of the first mishnah in the tractate (1:1) is a microcosm of his book as a whole. He begins with an analysis of the pericope's structure and basic meaning, helpfully situating it within the context of Avot specifically and within Rabbinic Judaism more broadly. In a thoughtful study of the term "Torah" (he wisely resists the hopelessly-loaded term "Law") he carefully presents the crucial Rabbinic claim regarding the transmission of a dual Torah, that is, the Oral Torah alongside the Written Torah. Drawing the (presumably Christian) reader into Rabbinic discourse, he explains the degree to which decisions about halakha (Rabbinic law) stand at the core of the Rabbis' project and how Rabbis develop their own body of law as a bulwark against violating biblical commandments. In sum, this section is an excellent short presentation of the core concepts and ideologies of Rabbinic Judaism. The "Christian Resonances" section which follows continues in this vein, presenting both similarities (e.g., a focus on a chain of tradition) and differences (e.g., the notion that Gentile Christians need not follow all the Torah's prohibitions and commands) with apostolic Christianity.

Here, as he does throughout the "Jewish Interpretations" sections, the author relies on a number of later Rabbinic, medieval, and modern commentaries, especially the two medieval recensions of the work known as Avot D'Rabbi Natan. This is helpful, in that it displays the breadth of the commentarial literature within the tradition. However, it also risks muddying the proverbial waters. Religious texts have meanings for generations long after they were written, but they are products of a particular time and place. At times Joslyn-Siemiatkoski's reliance on later commentaries obscures the original sense of the Mishnaic text. Jewish studies, at least in the classic Wissenschaft des Judentums sense, has sought to divorce the canonical texts from later interpretations. This commentary, on the other hand, does not.

Another flaw in the commentary section is the author's failure to adequately describe the oral process by which the Mishnah, including Avot, was created and transmitted during the classical Rabbinic period. The Mishnah is a distinctively oral "text." It was redacted in order to be memorized and then recited, first in the disciple-circles of Roman and Byzantine Palestine and later in the larger academies in Sassanid Babylonia. One cannot adequately discuss the content of Avot without first treating its form. There is a major difference between Jews and Christians in this period, between the hyper-textuality of the Church fathers and the pervasive orality of the Rabbis.

Over all, these are minor critiques. This commentary should be on the shelves of scholars of the New Testament and Patristics, and sections of it could profitably be assigned to courses on the Early Church. Most importantly however, this is a text which can help contemporary Christian audiences to understand something 
about Judaism's most important post-Biblical text simultaneously from the perspective of a Rabbinic insider and fellow (Christian) traveler. I warmheartedly recommend it. 